\title{
Assessment of Maxillofacial Trauma by Facial Injury Severity Score (FISS) System
}

\author{
Maya Madhuri ${ }^{1}$, Suneel Kumar Punjabi ${ }^{2}$, Anil Kumar ${ }^{1}$, Azra Khan ${ }^{1}$, Kashif Ali Channar ${ }^{2}$ and \\ Salman Shams ${ }^{3 *}$ \\ ${ }^{1}$ Resident, Oral and Maxillofacial Surgery Department, Faculty of Dentistry, Liaquat University of Medical and Health \\ Sciences, Pakistan \\ ${ }^{2}$ Associate Professor, Oral and Maxillofacial Surgery Department, Faculty of Dentistry, Liaquat University of Medical and \\ Health Sciences, Pakistan
}

${ }^{3}$ Senior Lecturer, Oral and Maxillofacial Surgery Department, Faculty of Dentistry, Liaquat University of Medical and Health Sciences, Pakistan

\begin{abstract}
Objective: To assess severity of maxillofacial trauma with help of Facial Injury Severity Score (FISS) System.

Subject and Methods: This is a Cross sectional study conducted at Oral and Maxillofacial Surgery Department of Liaquat University of Medical \& Health Sciences, Jamshoro/Hyderabad, Pakistan from August 2017 to August 2018. Data was collected from 167 patients admitted in Oral \& Maxillofacial Surgery Department, Liaquat University of Medical \& Health Sciences, Jamshoro/ Hyderabad, who met inclusion criteria. The FISS score was taken as the sum of all individual scores then final score was done and grouped according to mild, moderate and severe injuries.
\end{abstract}

Results: Minimum age was found 18 years and maximum age was 60 years with mean and standard deviation of the age was $37.29 \pm 12.65$ years. The minimum FISS Score was 1 and maximum was 14 . Males were 100/167 (59.9\%) while females were $67 / 167$ (40.1\%). There was no significant association found between Severity Score and all effect modifiers like gender and age.

Conclusion: It was concluded that in maxillofacial trauma the minimum FISS Score was 1 and maximum was 10 at Liaquat university hospital Hyderabad, Pakistan. The Severity of FISS score was found Moderate (FISS score 4-7). There was no significant association found between Severity Score and effect modifier like and gender.

KEYWORDS: Maxillofacial Trauma, Facial Injury Severity Score (FISS) System, Assessment

\section{INTRODUCTION}

Injuries to maxillofacial regions are amongst the most complicated issues to be tackled by health care professionals globally. Prevalence and diversity of facial lesions have generated a special interest in this field [1,2]. Facial skeleton fractures are mostly connected with major morbidity, functional defect and a very high cost of treatment [1]. Just like the etiology of trauma in other body regions, etiology in facial trauma is also the same. But because of compact and intricate facial anatomy, the consequences are worse than ones imaginations3. The most frequent causes include natural disasters, firearm injuries, assaults, sports and motor vehicle accidents [3-5]. Occurrence and epidemiological
Quick Response Code:

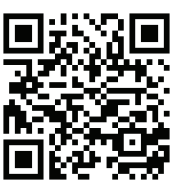

Address for correspondence: Salman Shams, BDS, MSc. Senior Lecturer, Department of Oral and Maxillofacial Surgery, Liaquat University of Medical \& Health Sciences, Pakistan

Received: August 17, $2020 \quad$ Published: August 27, 2020

How to cite this article: Maya M, Suneel Kumar P, Anil K, Azra K, Kashif Ali C, Salman S. Assessment of Maxillofacial Trauma by Facial Injury Severity Score (FISS) System. 2020 - 2(4) OAJBS.ID.000211. DOI: $10.38125 /$ OAJBS.000211 
causes of maxillofacial trauma vary in various regions of the world due to different economic, social and cultural status, acceptance of traffic regulation and consumption of alcohol $[1,4,6]$. Recent studies demonstrate that the major cause of maxillofacial trauma in more economically developed countries is interpersonal violence, whereas in underdeveloped and developed countries road traffic accident is the leading cause $[1,5,6]$.

Sometimes these injuries are isolated fractures but mostly connected with other serious and fatal injuries including head injuries, upper and lower limb injuries and chest injuries5,7. A study shows that $50-80 \%$ cases include head injuries and thus may involve a team of various medical professionals.

Patients of 20-29 years and especially males are the most affected ones with maxillofacial trauma. Fractures of mandible (with condylar region as most usual) followed by maxilla, isolated zygomatic bone and nasal bone are the most common forms of maxillofacial trauma [7].

Maxillofacial fractures are treated by close reduction and open reduction and internal fixation (ORIF) which also depends upon patient's age, kind and severity of fracture, status of teeth, fracture of other body organs and availability of resources. Techniques used for closed reduction are Erich bars, Ivy loops, Risdon's method of wiring, Inter-maxillary fixation screws and splints [8]. Methods for open reduction include mini plates and trans-osseous wiring [9].

Since 1970, a number of scoring systems have evolved for measuring severity level in trauma patients. Most of them only evaluate trauma in general, but with the advancement of Science, many effective systems have evolved for evaluating maxillofacial trauma in simplest way. Facial Injury Severity Score (FISS) is one of such examples $[10,11]$.

FISS, first suggested by Bagheri et al in 2006, has pre-defined values with variables responsible for various facial fractures10-12. This system has been introduced in many journals. But due to the unfamiliarity of its advantages, it is not seemed to be in usual practice $[10,11]$. It categorizes and grades maxillofacial fractures which in turn are based on their anatomic location in lower, middle and upper $3^{\text {rd }}$ of face. Its primary benefit is that it is not just an effective indicator of facial fractures but also a valuable predictor for economic burden to the patient and hospitalization of patient [10-12].

In the study conducted by Kesuma et al. [11] the severity of Maxillofacial Trauma with FISS scoring system, the mild cases were $18.3 \%$, moderate were $9.1 \%$ and the severe injuries were $1.4 \%$. The basic objective of our study is to categorize the fractures in accordance with FISS system so that surgeons can not only solve the complexities of maxillofacial anatomy but also warn the patients and their family in advance about the economic liability and days of hospitalization. It will also allow the surgeon to predict the severity of injury so that they can make appropriate treatment planning for better prognosis.

\section{MATERIALS AND METHODS}

This is a cross sectional study with Non-probability consecutive sampling technique conducted at Oral and Maxillofacial Surgery Department of Liaquat University of Medical \& Health Sciences, Jamshoro/Hyderabad, Pakistan from August 2017 to August 2018. Sample Size: Sample size was calculated by using WHO sample size calculator, taken statics for moderate (FISS score 4-7) as $9.1 \%$ and margin of error as 4.5\%, the calculated sample size was 167 .

\section{INCLUSION CRITERIA}

a) Irrespective of gender.

b) Age Range 18 - 60 years.

c) Patient having facial soft tissue injuries (lacerations).

d) Patient having clinical and radiographic evidence of facial bone fracture and are presenting within one week.

\section{EXCLUSION CRITERIA}

a) Isolated nasal bone fracture (Evaluated by CT $\backslash 3 \mathrm{D}$ scan of face).

b) Isolated dental injuries (Evaluated by CT \3D scan of face).

c) Patients suffering from debilitating diseases.

\section{Data Collection Procedure}

Data was collected from patients admitted in Oral \& Maxillofacial Surgery Department, Liaquat University of Medical \& Health Sciences, Jamshoro/Hyderabad, who meeting inclusion criteria. Informed consent was taken from the patient/attendant by researcher. Patients with maxillofacial trauma will be diagnosed by significant clinical and radiological evaluation. Any injury to the face either soft tissue or hard tissue were examined and scored according to FISS system. CT scan and 3D scan of the face is taken for diagnosis. Anatomical region and type of fracture is noted, four parameters are designated to classify the facial injuries and after that these are given a particular score.

For example, facial laceration less than $10 \mathrm{~cm}$ is given point zero while above $10 \mathrm{~cm}$ given point one. If dento-alveolar injury of maxilla present point one is given. The final FISS score will be the sum of all individual scores. This final score is then grouped according to mild, moderate and severe injuries. Data was analyzed by statistical software package SPSS version 22.0.

\section{Parameters}

a) Facial Laceration

b) Upper Facial Injuries (fracture orbital roof/rim, fracture into frontal sinus)

c) Injuries to The Mid-Face (dento-alveolar, fractures)

d) Injuries to The Mandible (dento-alveolar, fractures); (Table 1).

\section{RESULTS}

From 167 patients, it was observed that the minimum age was found 18 years and maximum age was 60 years with mean and standard deviation of the age was $37.29 \pm 12.65$ years. The minimum FISS Score was 1 and maximum was 10. Males were 100/ 167 (59.9\%) while females were 67/ 167 (40.1\%), see Table 2. Males were in high numbers as compared to females, see Figure 1.

The Severity of FISS score was found as Mild (FISS score 1-3) in 54/167 (32.3\%), Moderate (FISS score 4-7) in 80/167 (47.9\%) and Severe injuries (FISS score 8-15) in 33/ 167 (19.8\%), see Table 3. When the Chi-square test was applied, there was no significant association between Severity Score and gender having $p$-value = 0.803 see Table 4 .

After applying Chi-square test, it was found that there was no significant association exits between Severity Score and age having $p$-value $=0.362$ see Table 5 . 
Table 1:

\begin{tabular}{|c|c|c|}
\hline Parameter & Finding & Points \\
\hline \multirow{2}{*}{ Facial laceration } & $\leq 10 \mathrm{~cm}$ & 0 \\
\hline & $>10 \mathrm{~cm}$ & 1 \\
\hline \multirow{2}{*}{ Fracture of the orbital roof or rim } & Absent & 0 \\
\hline & Present & 1 \\
\hline \multirow{3}{*}{ Fracture into frontal sinus or bone } & Absent & 0 \\
\hline & Nondisplaced & 1 \\
\hline & Displaced & 5 \\
\hline \multirow{2}{*}{ Dento-alveolar injury of the maxilla } & Absent & 0 \\
\hline & Present & 1 \\
\hline \multirow{7}{*}{ Le Fort fracture } & None & 0 \\
\hline & unilateral type I & 1 \\
\hline & bilateral type II & 2 \\
\hline & unilateral type II & 2 \\
\hline & bilateral type II & 4 \\
\hline & unilateral type III & 3 \\
\hline & bilateral type III & 6 \\
\hline \multirow{2}{*}{ Naso-orbital-ethmoid (NOE) fractures } & None & 0 \\
\hline & Present & 3 \\
\hline \multirow{2}{*}{ Zygomatico-maxillary complex (ZMC) fracture } & Absent & 0 \\
\hline & Present & 1 \\
\hline \multirow{2}{*}{ Nasal fracture (alone) } & Absent & 0 \\
\hline & Present & 1 \\
\hline \multirow{2}{*}{ Dento-alveolar injury of mandible } & Absent & 0 \\
\hline & Present & 1 \\
\hline \multirow{2}{*}{$\begin{array}{l}\text { Fracture of mandibular body, ramus and/or } \\
\text { symphysis }\end{array}$} & Absent & 0 \\
\hline & Present & $2 \times<$ number $>$ \\
\hline \multirow{2}{*}{$\begin{array}{l}\text { Fracture of mandibular sub-condyle, condyle or } \\
\text { coronoid process }\end{array}$} & Absent & 0 \\
\hline & Present & $<$ number $>$ \\
\hline
\end{tabular}

Table 2: Descriptive Statistics $(n=167)$.

\begin{tabular}{|c|c|c|c|c|}
\hline & Minimum & Maximum & Mean & 37.29 \\
\hline Age & 18 & 60 & 12.65 & 4.98 \\
\hline FISS Score & 1 & 10 & 2.64 \\
\hline
\end{tabular}

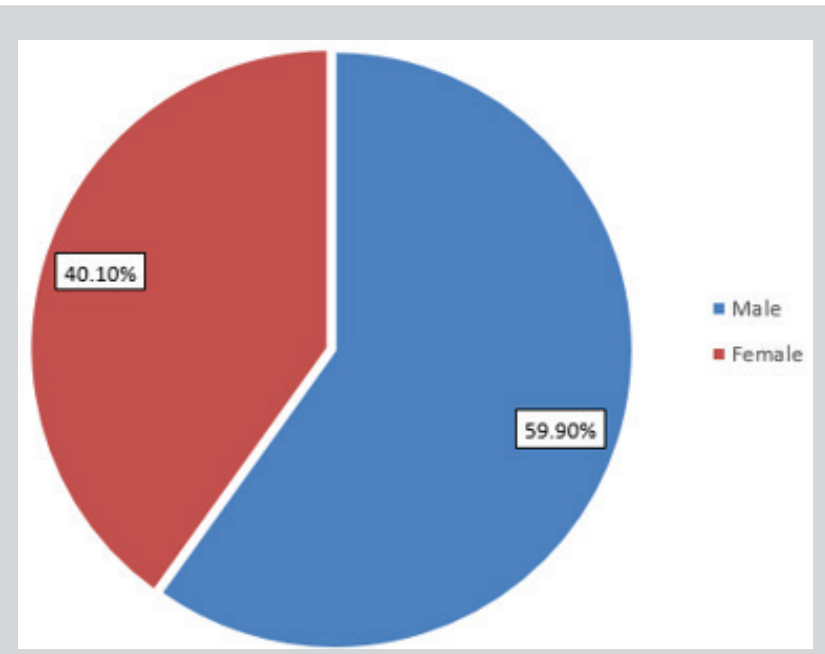

Figure 1: Pie chart of gender. 
Table 3: Distribution of severity.

\begin{tabular}{|c|c|c|}
\hline Severity & Frequency & Percent \\
\hline Mild (FISS score 1-3) & 54 & 32.3 \\
\hline Moderate (FISS score 4-7) & 80 & 47.9 \\
\hline Severe (FISS score 8-15) & 33 & 19.8 \\
\hline Total & 167 & 100 \\
\hline
\end{tabular}

Table 4: Stratification of Gender with respect to FISS ( $n=167$ ).

\begin{tabular}{|c|c|c|c|c|c|}
\hline \multirow{2}{*}{ Gender } & \multicolumn{3}{|c|}{ Severity Score (FISS) } & \multirow{2}{*}{ Total } \\
\hline & Mild (FISS score 1-3) & Moderate (FISS score 4-7) & Severe injuries (FISS score 8-15) & 19 & 100 \\
\hline Male & 31 & 50 & 14 & 67 \\
\hline Female & 23 & 30 & 33 & 0.803 \\
\hline Total & 54 & 80 & 167 & \\
\hline
\end{tabular}

Table 5: Stratification of age with respect to FISS ( $n=167$ ).

\begin{tabular}{|c|c|c|c|c|c|}
\hline \multirow{2}{*}{ Age } & \multicolumn{3}{|c|}{ Severity Score (FISS) } & \multirow{2}{*}{ Total } & \multirow{2}{*}{-value } \\
\cline { 2 - 6 } & Mild (FISS score 1-3) & Moderate (FISS score 4-7) & Severe Injuries (FISS score 8-15) & 17 & 0.362 \\
\hline$<40$ years & 33 & 39 & 16 & 78 \\
\hline$>40$ years & 21 & 41 & 33 & 167 & \\
\hline Total & 54 & 80 & 17 & 79 \\
\hline
\end{tabular}

\section{DISCUSSION}

In this present study, from 167 patients, it was observed that the minimum age was found 18 years and maximum age was 60 years with mean and standard deviation of the age was $37.29 \pm$ 12.65 years. The minimum FISS Score was 1 and maximum was 10. In this current study, there were $59.9 \%$ male patients which were more than female patients were $67 / 167$ (40.1\%). Severity of FISS score was found as Mild (FISS score 1-3) in 54/167 (32.3\%), Moderate (FISS score 4-7) in 80/167 (47.9\%) and Severe injuries (FISS score 8-15) in 33/ 167 (19.8\%).

In previous study, there is no relationship between FISS with head and cervical injury. However, FISS can still be used as a meaningful assessment of the severity of maxillofacial trauma and determine prompt and appropriate management. FISS can also be used as a tool of communication to other health personnel to accurately determine the severity and management in patients with maxillofacial trauma. The average FISS Score was $3.00 \pm 1.43$ with a minimum value of 1 , a maximum score of 6 , and the most patients had FISS 2 (25.8\%) and 4 (25.8\%) [13].

Same results were consistent with research conducted by Bangun [14] which states that the average FISS is $3.37 \pm 1.9$ with minimum value 1 and maximum 9, and most with FISS 2 (24,7\%). From these results can be concluded that all trauma has a minimum score. The difference in the range of FISS values is not too far due to the low acceleration of trauma in Jakarta caused by the high rate of traffic, the discipline in obeying traffic signs, which in turn can lead to maxillofacial trauma.

\section{CONCLUSION}

It was concluded that in maxillofacial trauma the minimum FISS Score was 1 and maximum was 10 at Liaquat university hospital Hyderabad, Pakistan. The Severity of FISS score was found Moderate (FISS score 4-7). There was no significant association found between Severity Score and effect modifier like and gender.

\section{REFERENCES}

1. Shaikh MI, Rajput F, Khatoon S, Usman G (2014) Etiology and incidence of maxillofacial skeletal injuries at tertiary care hospital, Larkana, Pakistan. Pak Oral Dent J 34(2): 239-241.

2. Rana ZA, Khoso NA, Arshad O, Siddiqi KM (2010) An assessment of maxillofacial injuries: a 5-year study of 2112 patients. Ann Pak Inst Med Sci 6(2): 113-115.

3. Punjabi SK, Rehman HU, Ali Z, Ahmed S (2011) Causes and management of zygomatic bone fractures at abbasi shaheed hospital karachi (analysis of 82 patients). J Pak Med Assoc 61(1): 36-39.

4. Arslan ED, Solakoglu AG, Komut E, Kavalci C, Yilmaz F, et al. (2014) Assessment of maxillofacial trauma in emergency department. World J Emerg Surg 9(13): 17.

5. Scheyerer MJ, Döring R, Fuchs N, Metzler P, Sprengel K (2015) Maxillofacial injuries in severely injured patients. J Trauma Manag Outcomes 9(4): 1-9.

6. Ahmed S, Punjabi SK, Rehman HU, Aslam MA, Haider SM, et al. (2014) Analysis of maxillofacial injuries spread over one-year period in Karachi sample. Pak Oral Dent J 34(1): 50-53.

7. Punjabi SK, Khan M, Hassan QU, Nisa ZU (2012) Associated injuries with facial trauma-a study. J Liaquat Uni Med Health Sci 11(2): 60-63.

8. Verma G (2013) Extended eyelet method: a new technique for maxillomandibular fixation. Global J Surg 1(4): 41-43.

9. Handa A, Shrikant SS, Rana SS, Mantri R, Sharma M, Virani R (2015) Transosseous wire fixation: an obsolete, yet valuable method for surgical management of facial fractures. J Oral Maxfacio Surg 1(3): 94-100.

10. Ramalingam S (2015) Role of maxillofacial trauma scoring systems in determining the economic burden to maxillofacial trauma patients in India. J Int Oral Health 7(4): 38-43. 
11. Kesuma AD, Bangun K (2012) Evaluation of facial trauma severity in cipto mangunkusumo hospital using FISS scoring system. J Plastik Rekonstuksi 1(2): 162-165.

12. Ramalingam S, Nooh N, Neelakandan R (2013) The impact of maxillofacial trauma scoring systems in predicting maxillofacial injury severity in developing countries. Int J Oral Maxilofac Surg 42(10): 12321233.
13. Manalu EE, Tarigan UA, Buchari FB (2018) The relationship between facial injury severity scale (FISS) with head and cervical injury at Adam Malik Medan central general hospital. International Journal of Medical Science and Clinical invention 5(5): 3810-3815.

14. Kayu DK, Bangun K (2012) Evaluation of Facial trauma Severity in Cip to Mangunkusumo Hospital Using FISS Scoring System. Jurnal Plastik Rekonstruksi 1(2): 162-165. 